\title{
THE TEMPORAL SCOPE OF THE EUROPEAN SUCCESSION REGULATION AND THE (IN-)VALIDITY OF JOINT WILLS UNDER POLISH LAW. COMMENTARY ON THE JUDGMENT OF THE SCHLESWIG HIGHER REGIONAL COURT OF 25 APRIL 2016, 3 WX 122/15*
}

\author{
EL ÁMBITO TEMPORAL DEL REGLAMENTO EUROPEO DE \\ SUCESIONES Y LA (IN)VALIDEZ DE LAS VOLUNTADES \\ CONJUNTAS EN ATENCIÓN AL DERECHO POLACO. \\ COMENTARIO A LA SENTENCIA DEL SCHLESWIG HIGHER \\ REGIONAL COURT DEL 25 DE ABRIL DE 2016, 3 WX 122/15
}

\author{
LAURA NASSE \\ Doctoral candidate and research assistant \\ Heidelberg Institute for Comparative Law, Conflict of Laws and International Business Law \\ University of Heidelberg, Germany
}

Recibido: 20.07.2019 / Aceptado: 29.08.2019

DOI: https://doi.org/10.20318/cdt.2018.4411

\begin{abstract}
The European Succession Regulation (Regulation (EU) No 650/2012) entered into force on 16 August 2012 and applies since 17 August 2015. To facilitate the application of the Regulation, the German legislator introduced a "Law on International Succession Law and the Amendment of Provisions on Certificates of Inheritance and other areas". One aspect of the new German law is the amendment of Article 25 of the Introductory Act to the German Civil Code (EGBGB) which now provides that chapter III of the Succession Regulation shall also apply to successions that do not fall within the Regulation's scope of application. In its decision, the Schleswig Higher Regional Court found that Article 25 EGBGB only extends the material but not the temporal scope of the Regulation. Furthermore, it discussed the characterization of the Polish prohibition of joint wills and found that the joint will of a Polish citizen who had been living in Germany is valid under the applicable German law.
\end{abstract}

Keywords: European Succession Regulation, temporal scope, prohibition of joint wills, applicable law, choice of law.

Resumen: El Reglamento europeo de sucesiones (Reglamento (UE) n $n^{0}$ 650/2012) entró en vigor el 16 de agosto de 2012 y se aplica desde el 17 de agosto de 2015. Para facilitar la aplicación del Reglamento, el legislador alemán introdujo una "Ley de derecho sucesorio internacional y la enmienda de las Disposiciones sobre Certificados de Herencia y otras áreas “. Un aspecto de la nueva ley alemana es la modificación del artículo 25 de la Ley introductoria del Código Civil alemán (EGBGB) que establece que el capítulo III del Reglamento de Sucesiones se aplicará también a las sucesiones que no entran en el ámbito de aplicación del Reglamento. . En su decisión, el Tribunal Regional Superior de Schleswig

\footnotetext{
*For the court's reasoning see Schleswig Higher Regional Court 25 April 2016-3 Wx 122/15, Neue Juristische Wochenschrift Rechtsprechungs-Report Zivilrecht (NJW-RR), 2016, pp. 1229-1233.
} 
consideró que el artículo 25 EGBGB solo extiende el alcance material pero no temporal del Reglamento. Además, discutió la caracterización de la prohibición polaca de voluntades conjuntas y encontró que la voluntad conjunta de un ciudadano polaco que había estado viviendo en Alemania es válida bajo la ley alemana aplicable.

Palabras clave: Reglamento europeo de sucesiones, ámbito temporal, prohibición de voluntades cojuntas, ley applicable, elección de ley.

Summary: I. Introduction. II. Facts of the case. III. The court's decision. 1. Applicability of the European Succession Regulation. 2. Validity of the joint will. 3. Implied choice of German Succession Law. 4. Testamentary capacity. 5. Ruling of the court. IV. Commentary. 1. The temporal scope of the European Succession Regulation. 2. Validity of the joint will. 3. Implied choice of law. 4. Testamentary capacity. V. Conclusions.

\section{Introduction}

1. In many legal systems, including Spain (Article 669 Código civil), joint wills are prohibited. ${ }^{1}$ This may cause problems if a succession issue involves a choice of law question and the joint will is only valid under one of the potentially applicable laws. ${ }^{2}$

2. In its decision, rendered on 25 April 2016, the Schleswig Higher Regional Court had to decide whether a joint will that a Polish citizen had drawn up along with his German wife is valid. Under Polish succession law joint wills are prohibited (Article 942 of the Polish Civil Code ${ }^{3}$ ) whereas they are generally valid under German law (Section 2265 of the German Civil Code $\left(\mathrm{BGB}^{4}\right)$ ). Therefore, the main issue in the case was the question which law will apply to the will and consequently, whether the joint will is valid or not. This article will first present the facts and legal background of the case and then comment on the Higher Court's decision.

\section{Facts of the case}

3. On 15 October 2014, a Polish citizen died in Hamburg (Germany) after having been living in Germany for more than twenty years and being married to his German wife since 1990. As he did not have any children and his parents had died already, the only surviving dependents were his wife and his three sisters. Shortly before his death, the deceased had drawn up a "joint will" together with his wife in which they declared that the surviving spouse would be the sole heir of the person dying first. The wife's child and the husband's stepchild was determined as their final heir. After her husband's death, the

${ }^{1}$ Other examples are France (Art. 968 Code civil), Portugal (Art. 2181 Código civil), Italy (Art. 589 Codice civile), Greece (Art. 1717 Civil code) and the Netherlands (Art. 4:93 BW). See also T. Helms, „Erbvertrag und gemeinschaftliches Testament“, in J. BASEDow/K. J. Hopt/R. Zimmermann (eds.), Handwörterbuch des Europäischen Privatrechts, 2009, available at http://hwbeup2009.mpipriv.de/index.php/Erbvertrag_und_gemeinschaftliches_Testament (last access 17 July 2018).

2 M. MARGONSKI, ,Verbot von Erbverträgen und gemeinschaftlichen Testamenten im polnischen Recht“",Zeitschrift für die notarielle Beratungs- und Beurkundungspraxis (NotBZ), 2015, pp. 81, 84; D. LoOsCHELDERS, ,Zeitlicher Anwendungsbereich der EuErbVO und Qualifikation des Verbots von gemeinschaftlichen Testamenten im polnischen Recht“, Praxis des Internationalen Privat- und Verfahrensrechts (IPRax), 2017, pp. 580, 583 with reference to Italian law; D. LoOsCHELDERS, „Qualifikations- und Anpassungsprobleme bei deutsch-italienischen Erbfällen“, IPRax, 2016, pp. 349-353; S. FranKE, in W. BURANDT/D. RoJAHN (eds.), Erbrecht, $2^{\text {nd }}$ ed., München, C.H. Beck, 2014, Art. 26 EGBGB, para. 22.

3 Kodeks cywilny, Polish Civil Code of 23 April 1964, O.J. 1964 No. 16, item 93, English translation available at https:// supertrans2014.files.wordpress.com/2014/06/the-civil-code.pdf (last access 17 July 2018).

${ }^{4}$ Bürgerliches Gesetzbuch (BGB), German Civil Code in the version promulgated on 2 January 2002, Federal Law Gazette (Bundesgesetzblatt, BGBl.) 2002 I p. 42, 2909; 2003 I p. 738, last amended by Article 4 para. 5 of the Act of 1 October 2013, BGB1. 2013 I p. 3719, English translation provided by the Langenscheidt Translation Service, available at https://www.gesetze-im-internet.de/englisch_bgb/englisch_bgb.html\#p0027 (last access 17 July 2018). 
deceased's wife applied for a German Certificate of Inheritance naming her the sole heir of all movable and immovable assets located in Germany. However, the competent district court refused the application, arguing that the joint will is invalid under the applicable law. Under Polish law, the wife is not the sole heir but part of a community of heirs together with the deceased's sisters.

4. As a result, the widow filed an appeal before the Schleswig Higher Regional Court. She argued that under the revised version of Article 25 EGBGB, the law governing her husband's succession is determined in accordance with the European Succession Regulation ${ }^{5}$ and, consequently, German succession law 6 .

\section{The court's decision}

5. The Schleswig Higher Regional Court had to deal with four issues:

\section{Applicability of the European Succession Regulation}

6. The first issue the court had to deal with is whether the European Succession Regulation applies in this case. According to the transitional provision in Article 83(1) of the Succession Regulation, the Regulation "shall apply to the succession of persons who died on or after 17 August 2015". The appellant argued that the revised Article 25 of the Introductory Act to the German Civil Code (EGBGB) ${ }^{7}$ would provide that chapter III of the Regulation was applicable even though her husband died before the 17 August 2015.

7. The current version of Article 25 EGBGB is part of a new German "Law on International Succession Law and the Amendment of Provisions on Certificates of Inheritance and other areas" ${ }^{8}$ which was introduced to facilitate the application of the Succession Regulation. ${ }^{9}$ It states: "Insofar as the succession doesn't fall within the scope of application of Regulation (EU) No 650/2012, chapter III of this Regulation shall apply mutatis mutandis."

8. The widow argued that due to the lack of a special transitional provision, Article 25 EGBGB should apply to all cases concerning succession. Hence, according to Article 21(1) of the Succession Regulation, the applicable law in this case would be "the law of the State in which the deceased had his habitual residence at the time of death." Here, her husband had lived in Germany for several years which results in the application of German law under which joint wills by spouses are valid (Sections 2265-2272 BGB).

9. The court considered this argument and found that Article 25 EGBGB does not extend the temporal scope of the Succession Regulation..$^{10}$ Otherwise, legal succession of a person who died before

\footnotetext{
${ }^{5}$ Regulation (EU) No. 650/2012 of the European Parliament and of the Council of 4 July 2012 on jurisdiction, applicable law, recognition and enforcement of decisions and acceptance and enforcement of authentic instruments in matters of succession and on the creation of a European Certificate of Succession.

6 Sections 1922-2385 BGB (5 $5^{\text {th }}$ Book).

7 Introductory Act to the Civil Code in the version promulgated on 21 September 1994, BGB1. 1994 I p. 2494, last amended by Article 17 of the Act of 20 November 2015, BGB1. 2015 I 2010, English translation provided by PrIv.-Doz. Dr. Juliana Mörsdorf LL.M. (Univ. of CALIFornia, Berkeley), available at https://www.gesetze-im-internet.de/englisch_bgbeg/ englisch_bgbeg.html\#p0013 (last access 17 July 2018).

8 „Gesetz zum Internationalen Erbrecht und zur Änderung von Vorschriften zum Erbschein sowie zur Änderung sonstiger Vorschriften" [Law on International Succession Law and the Amendment of Provisions on Certificates of Inheritance and other areas] of 29 June 2015, BGBl. 2015 I p. 1041.

9 R. WAGNer/N. FENNER, ,Anwendung der EU-Erbrechtsverordnung in Deutschland“, Zeitschrift für das gesamte Familienrecht (FamRZ), 2015, p. 1668.

${ }_{10}$ Schleswig Higher Regional Court 25 April 2016 - 3 Wx 122/15, NJW-RR, 2016, p. 1229, paras. 18-24.
} 
the Succession Regulation came into force would change afterwards. ${ }^{11}$ This would contradict the German principle of universal succession (Section 1922(1) BGB) which stipulates that the estate passes to the heirs at the time of death. ${ }^{12}$ A similar principle also exists in Polish law (Article $992 \S 1$ of the Polish Civil Code).

10. The court declared that Article 25 EGBGB does not intent to change these principles. Instead, the provision wants to extend the material scope of the European Succession Regulation to aspects that are not explicitly covered by the Regulation but have been characterized as a matter of succession law under the national choice of law rules. ${ }^{13}$ Thus, Article 25 EGBGB does not have any retroactive effect on the application of the Succession Regulation to the succession of persons who died before the 17 August $2015 .{ }^{14}$ In these cases, the national choice of law rules govern the case. ${ }^{15}$

11. Consequently, the Higher Regional Court applied the German conflict of laws rules in Section 2369 BGB, Sections 105 and 343(1) of the Act on Proceedings in Family Matters an in Matters of Non-contentious Jurisdiction (FamFG) to determine whether it had jurisdiction to decide the case. ${ }^{16}$

\section{Validity of the joint will}

12. The court also found that, contrary to the district court's view, the joint will of the deceased and his wife is valid under the law that was determined in accordance with Polish choice of law rules. ${ }^{17}$

13. To determine the applicable law, the court referred to the old version of Article 25(1) EGBGB and concluded that this provision points to German succession law. ${ }^{18}$ Article 25(1) EGBGB states that the law applicable to the succession as a whole is the law of the State whose nationality the deceased had at the time of death. Because Article 4(1) EGBGB accepts renvoi, the provision leads to the old version of the Articles 64-66 of the Polish Act on Private International Law (Polish PIL Act). ${ }^{19}$

14. Article 64(2) of the Polish PIL Act states that the law applicable to the succession as a whole is the law of the State whose nationality the deceased possessed at the time of death. In contrast, the law applicable to the form of a testament and its revocation is determined separately according to Article 66 of the Polish PIL Act.

15. Article 66 of the Polish PIL Act refers to the Hague Convention on the conflicts of laws relating to the form of testamentary dispositions of 5 October $1961^{20}$ : According to its Article 1, a testamentary disposition shall be valid if its form complies with the internal law of the place where the testator made it (a), of a place in which the testator had his domicile (c) or his habitual residence (d) either at the time when he made the disposition, or at the time of his death. Furthermore, Article 4 of the Convention states that the Convention "shall also apply to the form of testamentary dispositions made by two or more persons in one document".

16. According to these provisions German law seems to be applicable to the validity of the joint will. However, since the Convention does not give any further definition of the "form of testamentary

${ }^{11}$ Schleswig Higher Regional Court 25 April 2016 - 3 Wx 122/15, NJW-RR, 2016, p. 1229, para. 21.

12 Schleswig Higher Regional Court 25 April 2016 - 3 Wx 122/15, NJW-RR, 2016, p. 1229, para. 21.

13 Schleswig Higher Regional Court 25 April 2016 - 3 Wx 122/15, NJW-RR, 2016, pp. 1229-30, paras. $21,22$.

14 Schleswig Higher Regional Court 25 April 2016 - 3 Wx 122/15, NJW-RR, 2016, p. 1230, para. 23.

15 Schleswig Higher Regional Court 25 April 2016 - 3 Wx 122/15, NJW-RR, 2016, p. 1230, para. 23.

16 Schleswig Higher Regional Court 25 April 2016 - 3 Wx 122/15, NJW-RR, 2016, p. 1229, para. 20.

17 Schleswig Higher Regional Court 25 April 2016 - 3 Wx 122/15, NJW-RR, 2016, pp. 1230-31, paras. 25-38.

18 Schleswig Higher Regional Court 25 April 2016 - 3 Wx 122/15, NJW-RR, 2016, pp. 1230-31, paras. 25-38.

19 Polish Act on Private International Law of 4 February 2011, O.J. 2011 No. 80, item 432, English translation provided by Mateusz Pilich/Andrzej W. Wiśniewski, 2012, available at https://www.pil.mateuszpilich.edh.pl/New_Polish_PIL.pdf (last access 17 July 2018).

${ }^{20}$ Convention on the conflicts of laws relating to the form of testamentary dispositions, concluded in the Hague on 5 October 1961, available at https://www.hcch.net/de/instruments/conventions/full-text/?cid=40 (last access 17 July 2018). 
dispositions", the court had to examine the Polish prohibition of joint wills in Article 942 of the Polish Civil Code to find out how to determine the applicable law in the present case. ${ }^{21}$

17. If characterized as a matter of material validity, the prohibition would be part of the law applicable to the succession as a whole and must be examined under Polish law. ${ }^{22}$ Yet, if the prohibition of joint wills serves for formal reasons, the formal validity is concerned and thus German substantive law would apply. ${ }^{23}$

18. Since such a characterization has to be made from the respective national point of view, ${ }^{24}$ the court asked whether the Polish law prohibits joint wills for material or for formal reasons. ${ }^{25}$ The court, therefore, refers to a national report on Poland by Ludwig, which argues that the majority of Polish scholarship understands the prohibition of joint wills as a part of the formal requirements. ${ }^{26}$ The court adopts this understanding and concludes that the validity of the will is determined by German substantive law (in accordance with Article 66 of the Polish PIL Act, Articles 1 (a), (c), (d) and 4 of the Hague Convention). ${ }^{27}$

19. Thus, the court did not consider the argumentation of the deceased's sisters. ${ }^{28}$ They had claimed that the will was invalid because the date and venue of the will as well as the appendix "this is my consistent will" before the deceased's signature were handwritten by his wife and not by him. However, as Section 2267(1) BGB only requires that both spouses have signed the joint will the formal requirements were met. $^{29}$

\section{Implied choice of German Succession Law}

20. In the following paragraphs the court examined whether the deceased also made an implied choice of German succession law because he drew up a joint will that is formally valid under German law. ${ }^{30}$

21. According to Article 64(1) of the Polish PIL Act, the testator may choose "the law of his nationality, of his place of permanent or habitual residence at the time of making such a will or at the moment of his death" as the law to govern his succession. ${ }^{31}$ Consequently, if he chooses German law, Article 64(1) of the Polish PIL Act refers back to German substantive law (see Art. 4(1), (2) EGBGB). ${ }^{32}$

21 Schleswig Higher Regional Court 25 April 2016 - 3 Wx 122/15, NJW-RR, 2016, p. 1230, para. 31.

22 Schleswig Higher Regional Court 25 April 2016 - 3 Wx 122/15, NJW-RR, 2016, p. 1230, para. 31.

23 Schleswig Higher Regional Court 25 April 2016 - 3 Wx 122/15, NJW-RR, 2016, p. 1230, para. 31.

24 Schleswig Higher Regional Court 25 April 2016 - 3 Wx 122/15, NJW-RR, 2016, pp. 1230-31, paras. 32, 34; K. THORN in Palandt Bürgerliches Gesetzbuch, 74 ${ }^{\text {th }}$ ed., München, C.H. Beck, 2015, Art. 26 EGBGB, para. 6; FrankE, above, n. 2, para. 22; G. Schotten/C. Schmellenkamp, Das Internationale Privatrecht in der notariellen Praxis, $2^{\text {nd }}$ ed., München, C.H. Beck, 2007, para. 316; more precisely and differentiated H. DöRnER in J. KROPHOLler (ed.), J. von Staudingers Kommentar zum Bürgerlichen Gesetzbuch, Berlin, Sellier - de Gruyter, 2007, Art. 25 EGBGB, paras. 322-26, with reference to the German Federal High Court of Justice (Bundesgerichtshof, BGH) 12 January 1967 - III ZR 25/66, Neue Juristische Wochenschrift (NJW), 1967, p. 1177.

${ }_{25}$ Schleswig Higher Regional Court 25 April 2016 - 3 Wx 122/15, NJW-RR, 2016, pp. 1230-31, paras. 32, 34.

26 I. Ludwig in L. Kroiss/Ch. AnN/J. MAYer (ed.), Nomos-Kommentar Bürgerliches Gesetzbuch, Vol. 5, $4^{\text {th }}$ ed., Baden-Baden, Nomos, 2014, National Report Poland, para. 18; see also MARGonski, NotBZ, 2015, pp. 81, 84.

27 Schleswig Higher Regional Court 25 April 2016 - 3 Wx 122/15, NJW-RR, 2016, p. 1231, paras. 34, 35.

28 Schleswig Higher Regional Court 25 April 2016 - 3 Wx 122/15, NJW-RR, 2016, p. 1231, paras. 37-38.

29 Schleswig Higher Regional Court 25 April 2016 - 3 Wx 122/15, NJW-RR, 2016, p. 1231, paras. 37-38.

30 Schleswig Higher Regional Court 25 April 2016 - 3 Wx 122/15, NJW-RR, 2016, p. 1231, para. 39.

31 English translation by PILICH/WIŚNIEWSKI, above, n. 19.

32 Also pointed out by the court in Schleswig Higher Regional Court 25 April 2016 - 3 Wx 122/15, NJW-RR, 2016, p. 1231, para. 40. 
22. In addition, the court pointed out that due to the lack of an explicit choice, an implicit choice of law can be sufficient. ${ }^{33}$ This is especially the case when the testator is referring to a legal instrument that the law of his nationality does not recognize. ${ }^{34}$ Here, the deceased may have made an implicit choice when he drew up a joint will. Because some scholarship considers this argument as insufficient, ${ }^{35}$ the court additionally refers to Section 2084 BGB which allows supplementary interpretation. ${ }^{36}$ In the court's opinion, due to the fact that the deceased had been informed about the Polish succession law and the invalidity of joint wills but still drew up a joint will, it is clear that, if he was asked, he would have chosen German law. ${ }^{37}$

\section{Testamentary capacity}

23. Lastly, the court had to deal with the question whether the deceased still had the capacity to make a will..$^{38}$ The deceased's sisters claimed that because of his state of health and his medication, their brother was not mentally competent when signing the joint will. HoeHowever, the court did not consider these facts sufficient for reasonable doubts about the deceased's capacity: According to Section 2229(4) $\mathrm{BGB}$, the lack of testamentary capacity requires a pathological mental disturbance, mental deficiency or derangement of the senses which the court did not see fulfilled in the present case. ${ }^{39}$

\section{Ruling of the court}

24. Based on the argumentation discussed above, the Schleswig Higher Regional Court ordered the probate court to issue a Certificate of Inheritance naming the appellant the sole heir of her husband's movable and immovable assets located in Germany. ${ }^{40}$

\section{Commentary}

25. When taking into consideration the results of the Schleswig Higher Regional Court, one must conclude that the court has rendered a persuasive decision. However, it must be noted that the court's reasoning is methodologically imprecise in some areas and not always plausible at first glance. ${ }^{41}$ The following sections will discuss these issues in more detail.

\section{The temporal scope of the European Succession Regulation}

26. To begin with, the court's conclusion that the temporal scope of the European Succession Regulation is not extended by the revised version of Article 25 EGBGB is correct. Nevertheless, one may criticize that the court could have come to this result in an easier way:

27. It is true that the wording of Article 25 EGBGB is quite neutral and does not indicate clearly whether the article provides a temporal and/or material extension of the Regulation's scope of application. ${ }^{42}$ However, as Schmidt has already pointed out, Article 25 EGBGB entered into force on 17 August

33 Schleswig Higher Regional Court 25 April 2016 - 3 Wx 122/15, NJW-RR, 2016, p. 1231, para. 41.

34 Schleswig Higher Regional Court 25 April 2016 - 3 Wx 122/15, NJW-RR, 2016, p. 1231, para. 41.

35 Dörner, above, n. 24, Art. 25 EGBGB, para. 535; R. Süss, ,Anmerkung zu OLG Zweibrücken 28.5.2002 - 3 W 218/01“, Zeitschrift für Erbrecht und Vermögensnachfolge (ZEV), 2003, p. 164.

${ }^{36}$ Schleswig Higher Regional Court 25 April 2016 - 3 Wx 122/15, NJW-RR, 2016, p. 1232, paras. 43-47.

37 Schleswig Higher Regional Court 25 April 2016 - 3 Wx 122/15, NJW-RR, 2016, p. 1232, para. 45.

38 Schleswig Higher Regional Court 25 April 2016 - 3 Wx 122/15, NJW-RR, 2016, pp. 1232-33, paras. 48-52.

39 Schleswig Higher Regional Court 25 April 2016 - 3 Wx 122/15, NJW-RR, 2016, pp. 1232-33, paras. 51, 52.

40 Schleswig Higher Regional Court 25 April 2016-3 Wx 122/15, NJW-RR, 2016, p. 1233, para. 55.

41 Looschelders, IPRax, 2017, p. 580; J. P. Schmidt, „Anmerkung zu OLG Schleswig 25.4.2016 - 3 Wx 122/15“, FamRZ, 2016, pp. 1611-13; Тн. RauscheR, „Die Entwicklung des Internationalen Privatrechts 2015 bis 2016“, NJW, 2016, pp. 3493 , 3497.

${ }^{42}$ Schmidt, FamRZ, 2016, p. 1611; A. Dutta in J. v. Hein (ed.), Münchener Kommentar zum BGB, Vol. 11, $7^{\text {th }}$ ed., München, C.H. Beck, 2018, Art. 25 EGBGB, para. 2. 
$2015 .{ }^{43}$ It is a general known principle that new rules do not have any retroactive effects if there are no special transitional provisions. ${ }^{44}$ Consequently, it is obvious that Article 25 EGBGB is temporally not applicable to cases where the deceased died before the 17 August $2015 .{ }^{45}$ Therefore, it was unnecessary for the court to argue with the article's sense and purpose. ${ }^{46}$

28. In addition, as the court only mentioned briefly, there is no need for a transitional EGBGB provision because there already exists a European one in Article 83(1) of the Succession Regulation which impacts the application of national law. ${ }^{47}$ Article 83(1) states that the Regulation only applies to the succession of persons who died on or after the 17 August 2015..$^{48}$ If Article 25 EGBGB would extend the temporal scope of the Regulation there would be a clear conflict between European and national law which would be opposed to the European legislator's purposes to implement a consistent system of transitional provisions that, inter alia, shall protect the deceased's interest in a stable succession. ${ }^{49}$

\section{Validity of the joint will}

29. Regarding the validity of the deceased's joint will the court's judgement is not persuasive because the court did not apply the correct German choice of law rules for successions before the 17 August 2015..$^{50}$

30. As discussed above, the court only referred to the old version of Article 25 EGBGB and incidentally applied Polish private international law (Article 66 of the Polish PIL Act) and the Hague Convention on the conflicts of laws relating to the form of testamentary dispositions (see infra).

31. Yet, Article 25 EGBGB (old version) only applies to the succession as a whole, whereas Article 26(1) EGBGB provides a special rule for the law applicable to the form of a testament. As Article 26(1) EGBGB also refers to the Hague Convention on the conflicts of laws relating to the form of testamentary dispositions, the final result for the applicable law would have been the same. However, from a methodological point of view, the court should have answered the question about the characterization of the prohibition of joint wills already when examining German choice of law. ${ }^{51}$ Moreover, - and to make matters even more complicated - the court failed to recognize that the scope of Article 25 EGBGB does not cover the material validity of a testament: Even though it leads to the same law, the court should have referred to Article 26(5) EGBGB (old version). ${ }^{52}$

32. Regarding the characterization of the prohibition of joint wills itself, the court rightly followed the majority of scholarship because there are no Polish court decisions as to whether joint wills are only prohibited for formal reasons or not. ${ }^{53}$ The set-up of the Polish Civil Code does not indicate

43 See also WaGner/Fenner, FamRZ, 2015, p. 1668.

44 Schmidt, FamRZ, 2016, pp. 1611, 1612 who also points out which dramatic consequences such a retroactivity could have; similar M. MARGONSKI, „Erbfolge nach in Deutschland lebendem Polen aufgrund konkludenter Rechtswahl in gemeinschaftlichem Testament, Anmerkung zu OLG Schleswig 25.4.2016 - 3 Wx 122/15“, ZEV, 2016, pp. 502, 507; R. WAGNER, „Erste Rechtsprechung (des EuGH) zur EuErbVO“, NJW, 2017, pp. 3755, 3757.

45 Schmidt, FamRZ, 2016, pp. 1611, 1612; see also K. Thorn in Palandt Bürgerliches Gesetzbuch, $77^{\text {th }}$ ed., München, C.H. Beck, 2018, Art. 83 EuErbVO, para. 2.

46 Looschelders, IPRax, 2017, pp. 580-581; also with reference to the sense of Art. 25 EGBGB Thorn, above, n. 45, Art. 25 EGBGB, para. 1; Сн. DöBereINER, „Das Gesetz zum Internationalen Erbrecht und zur Änderung von Vorschriften zum Erbschein“, NJW, 2015, pp. 2449, 2454.

47 Wagner/Fenner, FamRZ, 2015, pp. 1668, 1671; Wagner, NJW, 2017, pp. 3755, 3756; Dutta, above, n. 42, Art. 25 EGBGB, para. 7

48 RAUSCHER, NJW, 2016, pp. 3493, 3496.

49 DutTA, above, n. 42, Art. 25 EGBGB, para. 2.

50 See RAUSCHER, $N J W, 2016$, pp. 3493, 3497, who describes the court's reasoning as „extremely confusing“.

51 LOOSCHELDERs, IPRax, 2017, pp. 580, 581.

52 Schmidt, FamRZ, 2016, pp. 1611, 1612; see also Franke, above, n. 2, Art. 26 EGBGB, para. 35.

53 Margonski, ZEV, 2016, pp. 502, 507. 
how to interpret Article 942 because it is only part of the "general provisions on testaments" and not of the section on the "form of testaments". ${ }^{54}$ This is also the reason why the prevailing opinion focusses on the content and the extent of the prohibition: Since the prohibition does not apply to verbal testaments it only prohibits the joint process of making of the will and, therefore, has to be characterized as a matter of formal validity. ${ }^{55}$

33. Finally, one may ask how the same facts will be judged under the European Succession Regulation. First, the main difference is that in accordance with the general rule in Article 21 of the Succession Regulation, the law applicable to the succession as a whole is the law of the State in which the deceased had his habitual residence at the time of death - in the present case, this will lead to German succession law.

34. Notwithstanding, the question concerning the characterization of the Polish prohibition of joint wills also arises under European law. ${ }^{56}$ There are different possible solutions depending on the result of the characterization: ${ }^{57}$

35. If one distinguishes between formal or material validity, the law applicable to the prohibition in Article 942 of the Polish Civil Code, as a matter of form, would be determined according to Article 75(1) § 2 of the Regulation which, similarly to Article 26(1) EGBGB and Article 66 of the Polish PIL Act, refers to the Hague Convention. ${ }^{58}$ Others argue to determine the applicable law in accordance with the special rule on substantive validity, even if the joint will is prohibited for formal reasons (consistent characterization) ${ }^{59}$ Depending on how one characterizes a joint will - as an "agreement as to succession" within the meaning of Article 25 of the Succession Regulation or as "another disposition of property upon death" within the meaning of Article 24 - the applicable law will be determined according to the Articles 24 or 25 of the Regulation. ${ }^{60}$ In the present case, both solutions would lead to German succession law.

\section{Implied choice of law}

36. The fact that the court examined whether the deceased had implicitly chosen German law is a little bit surprising. ${ }^{61}$ The court had stated that the joint will was valid under the applicable German law. At the same time, the deceased's wife would have also been the sole heir under Polish law which was generally applicable to the succession as a whole (see infra).$^{62}$

37. In addition, the court's reasoning is, again, not very precise: It referred to Article 64 of the Polish PIL Act but then used German criteria to determine whether the deceased had made a choice regarding the applicable law or not. Instead, the court should have referred to Article 4(2) of the Polish PIL Act which states that a choice has to be made explicitly or must result clearly from the circumstances. ${ }^{63}$ Furthermore, from a Polish perspective, the choice of a German legal instrument that does not exist under Polish law can be sufficient for an implicit choice of German law. ${ }^{64}$ Because Article 64 of the Polish

\footnotetext{
${ }^{54}$ Margonski, NotBZ, 2015, pp. 81, 84.

55 Margonski, NotBZ, 2015, pp. 81, 84 with further references. He also explicitly recommends this interpretation to German courts.

56 LOOSCHELDERS, IPRax, 2017, pp. 580, 582.

57 Schmidt, FamRZ, 2016, pp. 1611, 1612 points out that it is disputed whether the differentiation between formal and material purposes also shall be made under the Succession Regulation.

58 LOOSCHELDERS, IPRax, 2017, pp. 580, 582.

59 DutTA, above, n. 42, Art. 24 EuErbVO, para. 3 with further references.

${ }^{60}$ DutTA, above, n. 42, Art. 24 EuErbVO, para. 3 with further references; MARGOnSKI, NotBZ, 2015, pp. 81, 85.

61 LOOSCHELDERS, IPRax, 2017, pp. 580, 582.

62 LOOSCHELDERS, IPRax, 2017, pp. 580, 582.

${ }_{63}$ MARgonski, ZEV, 2016, pp. 502, 507; SChMidt, FamRZ, 2016, pp. 1606, 1612 who considers the court's reasoning as a "mortal sin".

${ }^{64}$ Margonski, ZEV, 2016, pp. 502, 507.
} 
PIL Act allows to choose the law of the place of permanent or habitual residence, the choice would have also been valid under Polish choice of law rules. ${ }^{65}$

38. Moreover, Looschelders correctly observes that a choice could have been made for the immovable located in Germany. ${ }^{66}$ This should have been examined in accordance with Article 25(2) EGBGB (old version) which provides a special rule for the choice of law relating to immovables. ${ }^{67}$

\section{Testamentary capacity}

39. It is surprising that the courts' reasoning on the testamentary capacity lacks any remark about the applicable law. ${ }^{68}$ The testamentary capacity is generally governed by the law applicable to the succession as a whole at the time of the making of the testament (Article 26(5) EGBGB (old version)) ${ }^{69}$ In case of a choice of the applicable law, this law also applies to the testamentary capacity, here German law. ${ }^{70}$ The Articles 22(3) and 26(1) lit. a) of the Succession Regulation come to the same conclusion. $^{71}$

\section{Conclusions}

40. The Schleswig Higher Regional Court's decision is one of the first judgements on the new Article 25 EGBGB and the temporal scope of the Succession regulation. Even though Article 25 EGBGB shall help the courts to determine the scope of application of the new Succession Regulation some questions are still unanswered and will need to be clarified by the future case law. ${ }^{72}$ Unfortunately, the court did not have the opportunity to further clarify the material scope of Article 25 EGBGB. ${ }^{73}$

41. The characterization of a prohibition of joint wills as a matter of substantive or of formal validity has been a subject of several German court decisions before: Whereas the prohibitions have been characterized as a matter of material validity under Spanish, Italian, Portuguese and Croatian law, the contrary result was reached under French, Swiss and Dutch law. ${ }^{74}$ The Higher Regional Court's decision on Polish law joins this series of decisions about a problem that will most likely also arise under the new European Succession Regulation. ${ }^{75}$ Because the Succession Regulation introduces the law of the State in which the deceased had his habitual residence (Article 21 of the Regulation) as the applicable law, cases where the testator chooses a legal instrument that only exists under the law of his nationality but not under the law which applies to his succession may cause problems. ${ }^{76}$ Thus, the question of characterization will be more relevant in this particular case. ${ }^{77}$

65 Margonski, ZEV, 2016, pp. 502, 507; LoOschelders, IPRax, 2017, pp. 580, 582.

${ }^{66}$ LOOSCHELDERS, IPRax, 2017, pp. 580, 582.

${ }^{67}$ Looschelders, IPRax, 2017, pp. 580, 582; Schmidt, FamRZ, 2016, pp. 1606, 1612.

68 LOOSChELDERs, IPRax, 2017, pp. 580, 582-83.

69 Dörner, above, n. 24, Art. 25 EGBGB, para. 238; S. Lorenz/F. Wall in H. G. Bamberger et al. (ed.), Beck'scher Online-Kommentar BGB, 46 ${ }^{\text {th }}$ ed., München, C.H. Beck, 2018, Art. 26 EGBGB, paras. 11-12; A. Dutta in F. J. Säcker/R. RixeCKer/H. OetKer (ed.), Münchener Kommentar zum BGB, $6^{\text {th }}$ ed., München, C.H. Beck, 2015, Art. 26 EGBGB, para. 18; B. v. Hoffmann/K. Thorn, Internationales Privatrecht, $9^{\text {th }}$ ed., München, C.H. Beck, 2007, § 9 para. 41.

70 LOOSCHELDERS, IPRax, 2017, pp. 589, 583.

71 See D. Looschelders in R. Hüsstege/H.-P. Mansel (ed.), Nomos-Kommentar Bürgerliches Gesetzbuch, Vol. 6, $2^{\text {nd }}$ ed., Baden-Baden, Nomos, 2015, Art. 22 EuErbVO, para. 29; DutTA, above, n. 42, Art. 26 EuErbVO, paras. 4-5.

72 Wagner/Fenner, FamRZ, 2015, pp. 1668, 1671; Schmidt, FamRZ, 2016, pp. 1606, 1613.

73 Schmid, FamRZ, 2016, pp. 1606, 1613.

74 Schleswig Higher Regional Court 25 April 2016 - 3 Wx 122/15, NJW-RR, 2016, p. 1231, para. 33 with reference to Franke, above, n. 2, para. 22.

75 LOOSCHELDERs, IPRax, 2017, pp. 580, 583.

76 LOOSCHELDERs, IPRax, 2017, pp. 580, 583.

77 LoOsChelders, IPRax, 2017, pp. 580, 583. 
42. To avoid uncertainty arising from such characterization problems, it is advisable for the testator to choose the applicable law in accordance with Article 22 of the Succession Regulation. This provision is another example for the growing importance of party autonomy as a connecting factor in European private international law, in contract law as well as in personal matters such as family and succession law. ${ }^{78}$

78 See inter alia K. Kroll-Ludwigs, Die Rolle der Parteiautonomie im europäischen Kollisionsrecht, Tübingen, Mohr Siebeck, 2013; Сн. KoHLER, "Autonomie de la volonté en droit international privé: un principe universel entre libéralisme et étatisme”, Recueil des Cours 359 (2012), pp. 285-478, from p. 303; D. HeNRich, „Privatautonomie und Parteiautonomie im Familienrecht", in J. Kleinschmidt et al. (ed.), Strukturelle Ungleichgewichtslagen in der internationalen Streitbeilegung, Frankfurt am Main, PL Academic Research, 2016, pp. 25-38; M.-Pн. Weller/N. Benz/Сh. Thomale, „Rechtsgeschäftsähnliche Parteiautonomie“, Zeitschrift für Europäisches Privatrecht (ZEuP), 2017, pp. 250-280; J. v. HeIn in J. v. HeIn (ed.), Münchener Kommentar zum Bürgerlichen Gesetzbuch, $7^{\text {th }}$ ed., München, C.H. Beck, 2018, Einleitung zum IPR, para. 35. 